Uporaba klorofilmetra u procjeni zrelosti listova duhana fluecured za berbu

Use of a chlorophyll meter to evaluate the ripeness of flue-cured tobacco leaves for harvesting

Gršić, K., Čavlek, M.

Poljoprivreda/Agriculture

ISSN: $1848-8080$ (Online)

ISSN: 1330-7142 (Print)

http://dx.doi.org/10.18047/poljo.25.2.3

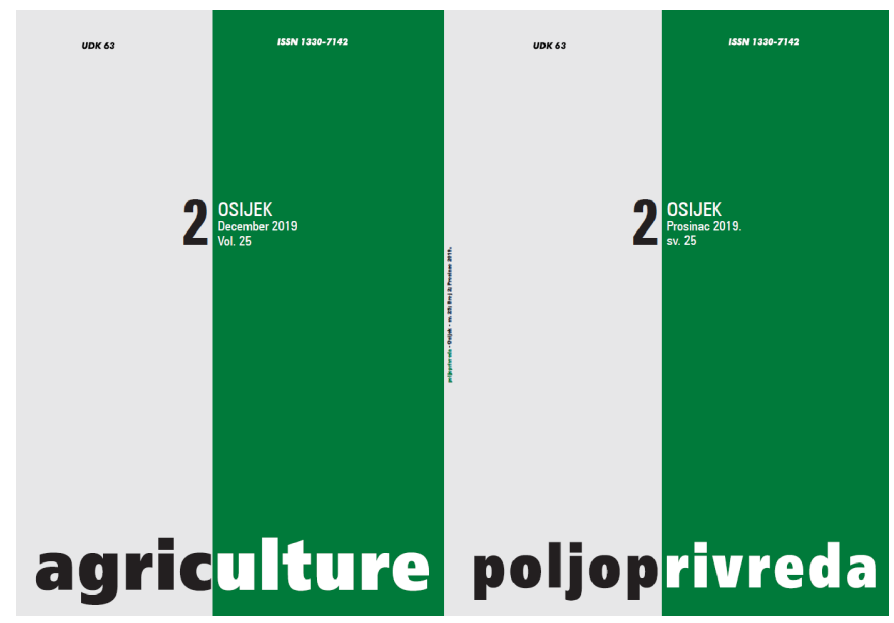

Fakultet agrobiotehničkih znanosti Osijek, Poljoprivredni institut Osijek

Faculty of Agrobiotechnical Sciences Osijek, Agricultural Institute Osijek 
ISSN 1330-7142

$U D K=633.71: 631.84^{\prime} 558$

DOI: $10.18047 /$ poljo.25.2.3

\section{UPORABA KLOROFILMETRA U PROCJENI ZRELOSTI LISTOVA FLUE-CURED DUHANA ZA BERBU}

Gršić, K. ${ }^{(1)}$, Čavlek, M. ${ }^{(2)}$

Izvorni znanstveni članak

Original scientific paper

\section{SAŽETAK}

Da bi se utvrdila mogućnost korištenja klorofilmetra u procjeni optimalne zrelosti listova flue-cured duhana za berbu, provedeni su dvogodišnji poljski pokusi. Postupci u pokusu bili su gnojidba dušikom (25 i 35 kg ha-T) i vrijeme berbe (rana, srednja i kasna berba). Relativni sadržaj klorofila 7., 11., 15. i 17. lista mjeren je u vrijeme berbe. Nakon berbe $i$ sušenja tih listova analizirani su prinos $i$ cijena te sadržaj nikotina i reducirajućih šećera.

Nije bilo signifikantnog utjecaja gnojidbe dušikom na prosječni prinos, cijenu $i$ sadržaj reducirajućih šećera. Međutim, dobivene su dvije interakcije gnojidba x vrijeme berbe za prinos. Viša gnojidba dušikom rezultirala je višim prosječnim sadržajem nikotina, ali samo u 15. i 17. listu u 2010. S obzirom na vrijeme berbe rezultati istraživanja su, uz nekoliko izuzetaka, pokazali da su viši prinosi, cijene, sadržaji nikotina i sadržaji reducirajućih šećera ostvareni srednjom ili/i kasnom berbom. Za pronalaženje raspona indeksa sadržaja klorofila u okviru kojeg bi se trebala provoditi berba listova duhana korišteni su matematički parametri odnosa između indeksa sadržaja klorofila u vrijeme berbe $i$ istraživanih svojstava. $U$ ovom istraživanju optimalno vrijeme za berbu listova duhana bilo je u rasponu indeksa sadržaja klorofila od 11-15.

Ključne riječi: flue-cured duhan, gnojidba dušikom, vrijeme berbe, indeks sadržaja klorofila

UVOD

Vegetativnu fazu razvoja biljaka duhana najznačajnije karakterizira apsorpcija dušika iz tla i redukcija nitrata a stadij dozrijevanja smanjenje fotosintetske aktivnosti kao posljedica razgradnje kloroplasta i remobilizacija dušika u gornje mlađe nerazvijene listove (Weybrew i sur., 1983.; Masclaux i sur., 2000.).

Količina dodanoga dušika i vlažnost tla tijekom vegetativne faze rasta i razvoja imaju najveći utjecaj na dozrijevanje duhana. Povećanje hranidbe dušikom do određene granice povećava prinos, cijenu i sadržaj nikotina i smanjuje sadržaj reducirajućih šećera, ali ti efekti ovise 0 vlažnosti tla tijekom vegetacije (Weybrew i sur., 1983.; Cavlek i sur., 1988.; Lyons i sur., 1996.; Çakir i Çebi, 2010.; Drake i sur., 2015.).

Literaturni podatci o utjecaju zrelosti lista na agronomske i kemijske karakteristike osušenih listova duha- na nisu jednoznačni. Walker (1964.) je ustanovio značajno niže prinose i cijene vrlo nezrelih listova u usporedbi s kasnijim stadijima zrelosti, između kojih nije bilo značajnijih razlika u cijeni. Weybrew i sur. (1984.) i Suggs (1986.) su ustanovili da je odlaganje berbe od nezrelosti prema prezrelosti generalno rezultiralo smanjenjem prinosa, a odlaganje do stadija zrelosti, odnosno jedan tjedan nakon optimalne zrelosti, povećanjem indeksa kvalitete odnosno cijene. Čavlek i Gršić (2008.) su u dva vršna segmenta u dva od četiri slučaja najviše prinose dobili berbom nezrelih listova, a u tri slučaja značajno nižu cijenu prezrelih listova u usporedbi s nezrelima i zrelim. Dosadašnja istraživanja generalno su pokazala da se povećanjem zrelosti povećavao sadržaj alkaloida

(1) Dr. sc. Kristina Gršić - Hrvatska agencija za poljoprivredu i hranu, Centar za zaštitu bilja, Gorice 68b, 10000 Zagreb; (2) Dr. sc. Miroslav Čavlek (u mirovini) (miro.cavlek@gmail.com) - Duhanski institut Zagreb d.o.o., Svetošimunska cesta 25, 10000 Zagreb 
odnosno nikotina u osušenim listovima (Weybrew i sur., 1984.; Suggs, 1986.; Čavlek i Gršić, 2008.; Taylor i sur., 2011.). U tim istraživanjima nije utvrđen generalni trend odnosa zrelosti i sadržaja reducirajućih šećera, iako su u nekim godinama pronađene značajne razlike.

Vizualni znaci zrelosti lista za berbu su promjena boje od zelene prema žućkastoj, promjena boje donje polovice rebra u mliječno bijelu te otklon listova od stabljike (Weybrew i sur., 1984.). Kowalczyk-Juśko i Kościk (2002.) su eksperimentalno utvrdili opadanje indeksa sadržaja klorofila s povećanjem zrelosti listova. Walker (1964.) je sadržaj klorofila u listovima različite zrelosti rangirao u sedam razreda, koji su se većinom podudarali s vizualnim procjenama zrelosti listova za berbu od vrlo nezrelih do prezrelih. Masclaux i sur. (2000.) su zaključili da je sadržaj klorofila dobar biomarker za procjenu relativne starosti lista, a Liang i sur. (2008.) su pokazali da je na temelju izmjerenih koncentracija klorofila i indeksa sadržaja klorofila moguće predvidjeti odgovarajuće vrijeme za berbu listova duhana. Kamarudin (2003.) je predložio raspone indeksa sadržaja klorofila na listovima na četiri položaja na stabljici unutar kojih bi trebalo izvršiti berbu berlejskog duhana koji se suši na stabljikama. Gršić i Čavlek (2010.) su u ranijem istraživanju optimalne agronomske rezultate dobili kada su listovi duhana na bazi indeksa sadržaja klorofila bili pobrani u rasponu 10 do15.

Cilj ovih istraživanja bio je proučiti mogućnost korištenja klorofilmetra kao dijagnostičkoga testa za procjenu zrelosti lista za berbu kroz istraživanja utjecaja gnojidbe i zrelosti listova u vrijeme berbe na prinos, cijenu, sadržaj nikotina i reducirajućih šećera flue-cured duhana.

\section{MATERIJAL I METODE}

Istraživanje je provedeno u 2009. i 2010. na lesiviranom tlu i pleistocenskim pijescima s pH oko 6,9, oko $0,95 \%$ humusa i $0,04 \% \mathrm{~N}$. Tlo je bilo vrlo dobro opskrbljeno fiziološki aktivnim kalijem i osrednje fosforom. Pokus je bio organiziran prema split-plot metodi u tri repeticije s faktorima "gnojidba dušikom“ i „vrijeme berbe“. Gnojidba duhana dušikom obavljena je s $25 \mathrm{~kg} \mathrm{ha}^{-1} \mathrm{~N} \mathrm{i} 35 \mathrm{~kg} \mathrm{ha}^{-1}$ $\mathrm{N}$, a berba 7., 11., 15. i 17. lista obavljena je na početku, sredinom i pri kraju stadija dozrijevanja. Biljke duhana su bile posađene na međuredni razmak od $100 \mathrm{~cm}$, a unutar reda na $43 \mathrm{~cm}$. Gnojidba duhana kompleksnim mineralnim gnojivom NPK formulacije 0:5:30 u količini $400 \mathrm{~kg}$ $\mathrm{ha}^{-1}$ provedena je širom pri pripremi gredica. Gnojidba dušikom obavljena je ručno kalcijevim nitratom oko dva tjedna nakon presađivanja prijesadnica u polje. Dušično gnojivo dodano je na udaljenost od oko $10 \mathrm{~cm}$ sa svake strane biljaka i na dubinu od oko $10 \mathrm{~cm}$. Sadnja duhana u polje 2009. i 2010. bila je 13. i 10. svibnja. Duhan je uzgajan u prirodnim uvjetima, bez navodnjavanja.

Paralelno s berbom 7., 11., 15. i 17. lista za procjenu agronomskih i kemijskih svojstava izmjeren je relativni sadržaj klorofila u listu. Mjerenja indeksa sadržaja klorofila provedena su sa svake strane rebra na tri mjesta na listu, na $5 \mathrm{~cm}$ od baze lista, na sredini i na vrhu lista. Relativni sadržaj klorofila izmjeren je klorofilmetrom CCM-200 (Opti-Sciences, Tyngsboro, Massachusetss, USA).

Klimatske prilike bile su dominantno određene količinama i rasporedom oborina tijekom različitih dijelova vegetacije (Tablica 1). Godina 2009. bila je obilježena izuzetno malom količinom oborina i vodnim stresom od druge dekade srpnja do završetka berbe. Ukupnih 709,8 $\mathrm{mm}$ oborina u vegetaciji duhana u 2010. neuobičajeno je visoka količina u tom uzgojnom području, s enormnih $451,5 \mathrm{~mm}$ u svibnju i lipnju.

Tablica 1. Neki meteorološki podatci kroz vegetaciju u 2009. i 2010.

Table 1. Some meteorological data during growing season in 2009 and 2010

\begin{tabular}{|l|c|c|c|c|}
\hline \multirow{2}{*}{$\begin{array}{l}\text { Mjesec } \\
\text { Month }\end{array}$} & \multicolumn{2}{|c|}{$\begin{array}{c}\text { Oborine, } \\
\text { Precipitation }(\mathrm{mm})\end{array}$} & \multicolumn{2}{c|}{$\begin{array}{c}\text { Temperatura }\left({ }^{\circ} \mathrm{C}\right) \\
\text { Temperature }\left({ }^{\circ} \mathrm{C}\right)\end{array}$} \\
\cline { 2 - 5 } & 2009. & 2010. & 2009. & 2010. \\
\hline V. & 38,8 & 192,7 & 17,7 & 16,3 \\
\hline VI. & 85,1 & 259,1 & 18,9 & 19,8 \\
\hline VII. & 66,1 & 69,6 & 21,8 & 22,9 \\
\hline VIII. & 28,5 & 60,7 & 21,8 & 20,7 \\
\hline IX. & 28,4 & 127,7 & 17,5 & 14,9 \\
\hline Zbroj - Sum & 246,9 & 709,8 & & \\
\hline
\end{tabular}

Nakon berbe, ubrani listovi duhana osušeni su u tipskim sušnicama za flue-cured duhan prema standardnoj proceduri za sušenje zrelih listova duhana. Po završetku procesa sušenja provedeno je vaganje i klasiranje osušenih listova za izračun prinosa i cijene, i uzimanje uzoraka za analizu glede sadržaja nikotina i reducirajućih šećera. Klasiranjem duhana sa svake osnovne parcelice listovi duhana bili su razvrstani u šest klasa. Na temelju težine i otkupne cijene za svaku klasu listova duhana izračunata je cijena u $\mathrm{kn} \mathrm{kg}^{-1}$ za svaki postupak. Podatci za istraživana agronomska i kemijska svojstva duhana, za svaki list zasebno, analizirani su korištenjem statističkoga programa mješovitoga postupka (mixed procedure) SAS-a (SAS Institute Inc., 2004.) i testirani u skladu s Fisherovim t-testom (Steel i Torrie, 1960.). Za procjenu odnosa između relativnoga sadržaja klorofila $i$ istraživanih svojstava provedena je regresijska analiza korištenjem prosječnih vrijednosti za ranu, srednju i kasnu berbu sa sva četiri istraživana položaja listova na stabljici.

\section{REZULTATI I RASPRAVA}

Nije bilo značajnoga utjecaja povećanja gnojidbe dušikom na prosječni prinos, cijenu, i sadržaj reducirajućih šećera. Stoga rezultati nisu prikazani niti u jednoj tablici. Međutim, reakcije prinosa na gnojidbu zabilježene su u interakcijama gnojidbe $x$ vrijeme berbe (Tablica 2). 
Tablica 2. Utjecaj gnojidbe dušikom na sadržaj nikotina i zajednički učinak gnojidbe dušikom i vremena berbe na prinos

Table 2. Effect of nitrogen fertilization on nicotine content, and common effect of nitrogen fertilization and harvesting time on yield

\begin{tabular}{|c|c|c|c|c|c|c|c|c|}
\hline \multirow{4}{*}{$\begin{array}{l}\text { Gnojidba } \\
\text { dušikom } \\
\text { Nitrogen } \\
\text { fertilizing }\end{array}$} & \multirow{2}{*}{\multicolumn{2}{|c|}{$\begin{array}{c}\text { Nikotin / Nicotine, } \% \\
2010 .\end{array}$}} & \multicolumn{6}{|c|}{ Prinos / Yield, $\mathrm{kg} \mathrm{ha}^{-1}$} \\
\hline & & & \multicolumn{3}{|c|}{2009.} & \multicolumn{3}{|c|}{2010.} \\
\hline & L 15 & $\mathrm{~L} 17$ & \multicolumn{3}{|c|}{ L 15} & \multicolumn{3}{|c|}{ L 11} \\
\hline & \multicolumn{2}{|c|}{ Prosjek tri vremena berbe } & \multicolumn{3}{|c|}{ Vrijeme berbe / Harvesting time } & \multicolumn{3}{|c|}{ Vrijeme berbe / Harvesting time } \\
\hline $\mathrm{kg} \mathrm{ha}^{-1}$ & \multicolumn{2}{|c|}{ Average of three harvesting times } & $\begin{array}{l}\text { Rana } \\
\text { Early }\end{array}$ & $\begin{array}{l}\text { Srednja } \\
\text { Middle }\end{array}$ & $\begin{array}{l}\text { Kasna } \\
\text { Late }\end{array}$ & $\begin{array}{l}\text { Rana } \\
\text { Early }\end{array}$ & $\begin{array}{l}\text { Srednja } \\
\text { Middle }\end{array}$ & $\begin{array}{l}\text { Kasna } \\
\text { Late }\end{array}$ \\
\hline 25 & $1,41 \mathrm{~b}$ & $1,34 \mathrm{~b}$ & $163 a A$ & $176 \mathrm{aA}$ & $158 \mathrm{bA}$ & $58 \mathrm{aB}$ & $151 \mathrm{aA}$ & $131 \mathrm{bA}$ \\
\hline 35 & $1,70 \mathrm{a}$ & $1,71 \mathrm{a}$ & $125 \mathrm{aB}$ & $203 a A$ & $203 a A$ & $49 \mathrm{aB}$ & $157 \mathrm{aA}$ & $180 \mathrm{aA}$ \\
\hline
\end{tabular}

L-list / L-leaf; Različita mala slova unutar istog stupca pokazuju značajnost kod $\mathrm{p}<0,05$ / Different lowercase letter within the same column indicate significance at $p<0.05$ : Različita velika slova unutar iste gnojidbe, godine i lista pokazuju značajnost kod $p<0,05$ / Different uppercase letter within the same fertilization, year and leaf indicate significance at $p<0.05$

Viši prinosi, kao rezultat povećanja gnojidbe dušikom s 25 na $35 \mathrm{~kg} \mathrm{ha}^{-1}$, evidentirani su samo kod kasne berbe 15. lista u 2009. i 11. lista u 2010. U postupku gnojidbe N $35 \mathrm{~kg} \mathrm{ha}^{-1}$ u 2009. rana berba 15. lista i u oba postupka gnojidbe u 2010. rana berba 11. lista rezultirala je značajno manjim prinosom u usporedbi sa srednjom i kasnom berbom. Učinci gnojibe na prosječan sadržaj nikotina evidentirani su samo za 15. i 17. list 2010. kada je povećanje gnojidbe dušikom za 10 $\mathrm{kg} \mathrm{ha}^{-1}$ rezultiralo većim sadržajem nikotina. Neznatan utjecaj povećanja gnojidbe dušikom, uz nekoliko izuzetaka, na istraživane karakteristike duhana vjerojatno je bio posljedica klimatskih prilika na dostupnost dušika u razvojnim fazama, ograničene apsorpcije uslijed nedostatne vlažnosti tla u 2009. odnosno ispiranja dušika uslijed preobilnih oborina u 2010. Neznatne razlike u prosječnim vrijednostima nekih agronomskih i/ili kemijskih svojstava između osušenih listova duhana gnojenih različitim količinama dušika u pojedinim godinama evidentirane su i u istraživanjima Weybrew $\mathrm{i}$ sur. (1983.), Čavlek i sur. (1988.), Lyons i sur. (1996.) i Drake i sur. (2015.).

Postojalo je značajno povećanje prinosa kako se stupanj zrelosti mijenjao od rane do srednje berbe. Jedini izuzetci bili su u berbi 7. i 11. lista 2009., kada razlike u prinosu $\mathrm{s}$ obzirom na vrijeme berbe nisu bile pronađene (Tablica 3). U 2010. godini prinosi, cijene i posljedično sadržaji nikotina i reducirajućih šećera za ranu berbu 15. i 17. lista nisu uzeti u obračun jer su listovi u vrijeme uzorkovanja bili manji od $20 \mathrm{~cm}$. Najviša cijena za 7. list 2009. postignuta je ranom berbom, uz neznatnu razliku sa srednjom berbom, dok su kod viših položaja na stabljici najviše cijene postignute srednjom berbom (Tablica 3). Naredne godine, najviša cijena za 7 . list ostvarena je srednjom, a za 11. list kasnom berbom, uz neznatnu razliku sa srednjom berbom. U berbama 15. i 17. lista kasna berba je rezultirala značajno višom cijenom u usporedbi sa srednjom berbom.

Tablica 3. Utjecaj vremena berbe na prinos, cijenu, sadržaj nikotina i sadržaj reducirajućih šećera flue-cured duhana u 2009. i 2010.

Table 3. Effect of time of harvest on yield, price, nicotine content and reducing sugars content of flue-cured tobacco in 2009 and 2010.

\begin{tabular}{|c|c|c|c|c|c|c|c|c|}
\hline \multirow{2}{*}{$\begin{array}{l}\text { Berba } \\
\text { Harvest }\end{array}$} & \multicolumn{2}{|c|}{$\begin{array}{l}\text { Prinos, } \mathrm{kg} \mathrm{ha}^{-1} \\
\text { Yield, } \mathrm{kg} \mathrm{ha}^{-1}\end{array}$} & \multicolumn{2}{|c|}{$\begin{array}{l}\text { Cijena, } \mathrm{kn} \mathrm{kg}^{-1} \\
\text { Price, } \mathrm{kn} \mathrm{kg}^{-1}\end{array}$} & \multicolumn{2}{|c|}{$\begin{array}{l}\text { Nikotin, \% } \\
\text { Nicotine, \% }\end{array}$} & \multicolumn{2}{|c|}{$\begin{array}{l}\text { Reducirajući šećeri, \% } \\
\text { Reducing sugars, \% }\end{array}$} \\
\hline & 2009. & 2010. & 2009. & 2010. & 2009. & 2010. & 2009. & 2010. \\
\hline \multicolumn{9}{|c|}{ 7. list / $7^{\text {th }}$ leaf } \\
\hline Rana / Early & $146 a$ & $89 \mathrm{~b}$ & $12,48 \mathrm{a}$ & $10,09 b$ & $0,88 \mathrm{~b}$ & $0,90 c$ & $19,76 a$ & $14,52 b$ \\
\hline Srednja / Middle & $136 a$ & $136 a$ & $10,20 a$ & $14,96 a$ & $1,11 \mathrm{ab}$ & $1,29 b$ & $14,65 b$ & $19,63 a$ \\
\hline Kasna / Late & $122 a$ & $127 a$ & $5,08 b$ & $10,56 b$ & $1,49 a$ & $1,51 \mathrm{a}$ & $7,45 c$ & $17,12 \mathrm{ab}$ \\
\hline \multicolumn{9}{|c|}{ 11. list $/ 11^{\text {th }}$ leaf } \\
\hline Rana / Early & $169 a$ & $53 b$ & $14,12 b$ & $4,07 \mathrm{~b}$ & $0,85 b$ & $0,63 c$ & $24,23 a$ & $8,68 \mathrm{~b}$ \\
\hline Srednja / Middle & 201a & $154 a$ & $17,56 \mathrm{a}$ & $11,46 a$ & $2,46 a$ & $1,26 \mathrm{~b}$ & $23,07 a$ & $18,36 \mathrm{a}$ \\
\hline Kasna / Late & 213a & $156 a$ & $13,47 \mathrm{~b}$ & $12,50 \mathrm{a}$ & $2,37 a$ & $1,63 a$ & $19,56 a$ & $19,36 \mathrm{a}$ \\
\hline \multicolumn{9}{|c|}{ 15. list / $15^{\text {th }}$ leaf } \\
\hline Rana / Early & $144 b$ & - & $8,55 \mathrm{c}$ & - & $0,61 b$ & - & $18,19 a$ & - \\
\hline Srednja / Middle & $189 a$ & $129 a$ & $16,20 \mathrm{a}$ & $10,01 b$ & $2,97 a$ & $1,34 b$ & $20,76 a$ & $18,3 a$ \\
\hline Kasna / Late & $180 a$ & $128 \mathrm{a}$ & $13,34 b$ & $12,73 a$ & $2,63 a$ & $1,77 a$ & $16,98 \mathrm{a}$ & $15,82 b$ \\
\hline \multicolumn{9}{|c|}{ 17. list $/ 17^{\text {th }}$ leaf } \\
\hline Rana / Early & $113 b$ & - & $6,60 \mathrm{~b}$ & - & $0,29 b$ & - & $13,66 \mathrm{~b}$ & - \\
\hline Srednja / Middle & $166 a$ & $107 a$ & $16,47 \mathrm{a}$ & $9,15 b$ & $2,68 \mathrm{a}$ & $1,39 a$ & $20,15 a$ & $16,11 \mathrm{a}$ \\
\hline Kasna / Late & $160 \mathrm{a}$ & $106 a$ & $13,65 a$ & $13,26 a$ & $2,76 a$ & $1,66 \mathrm{a}$ & $15,27 \mathrm{~b}$ & $15,73 a$ \\
\hline
\end{tabular}

U 2010. istraživana svojstva za ranu berbu 15. i 17. lista nisu analizirana / In 2010, investigated properties for early harvest of $15^{\text {th }}$ and $17^{\text {th }}$ leaf were not analyzed; Različita slova unutar istog stupca i lista pokazuju značajnost kod $p<0,05$ / Different letter within the same column and leaf indicate significance at $p<0.05$ 
Rezultati istraživanja u ovome pokusu glede prinosa i cijene podupiru Walkerova (1964.) istraživanja, koji je odlaganjem berbe od vrlo nezrelih prema zrelim listovima ostvario više prinose i cijene. Međutim, Weybrew i sur. (1984.) i Suggs (1986.) su ustanovili da odlaganje vremena berbe rezultira smanjenjem prinosa, a do jedan tjedan nakon optimalne zrelosti povećanjem indeksa kvalitete odnosno cijene. Čavlek i Gršić (2008.) su berbom nezrelih listova ostvarili više prinose, a berbom prezrelih listova nižu cijenu. Slične rezultate dobili su i Taylor i sur. (2011.) berbom listova nakon optimalne zrelosti.

U 2009. je odlaganje vremena berbe 7. lista od rane do kasne berbe, a listova na višim položajima na stabljici do srednje berbe, povećalo sadržaj nikotina (Tablica 3). Naredne godine najviši sadržaji nikotina na svim položajima na stabljici dobiveni su kasnom berbom $(1,51 \%$, $1,63 \%, 1,77 \%$ i 1,66\%). Povećanje sadržaja nikotina s povećanjem zrelosti listova u skladu je s ranijim istraživanjima (Weybrew i sur., 1984.; Suggs, 1986.; Taylor i sur., 2011.), iako takvi efekti nisu pravilo u svim godinama istraživanja (Čavlek i Gršić, 2008.). Sadržaj reducirajućih šećera u osušenim listovima različite zrelosti u 2009. nije bio konzistentan (Tablica 3). Najviši sadržaj reducirajućih šećera u 7. listu dobiven je ranom, a u 17. listu srednjom berbom. Međutim, različita zrelost u vrijeme berbe 11 . i 15. lista nije rezultirala značajnim razlikama u sadržaju reducirajućih šećera. U 2010. je viši sadržaj reducirajućih šećera ustanovljen u listovima srednje berbe, kod 7. i 11. lista značajno u usporedbi s ranom, a kod 15. lista u usporedbi s kasnom berbom. Weybrew i sur. (1984.), Suggs (1986.) i Gršić i Čavlek (2008.) i Taylor i sur. (2011.) nisu ustanovili trend odnosa između sadržaja reducirajućih šećera i zrelosti listova u vrijeme berbe.

Odlaganjem vremena berbe na svim listovima prema položaju na stabljici i u svim pozicijama mjerenja na listu (dno, sredina i vrh lista) ustanovljeno je smanjenje relativnoga sadržaja klorofila izraženog jedinicama indeksa sadržaja klorofila (Slika 1), što je u skladu s ranijim istraživanjima (Liang i sur., 2008.; Kamarudin, 2003.; Gršić i Čavlek, 2010.).

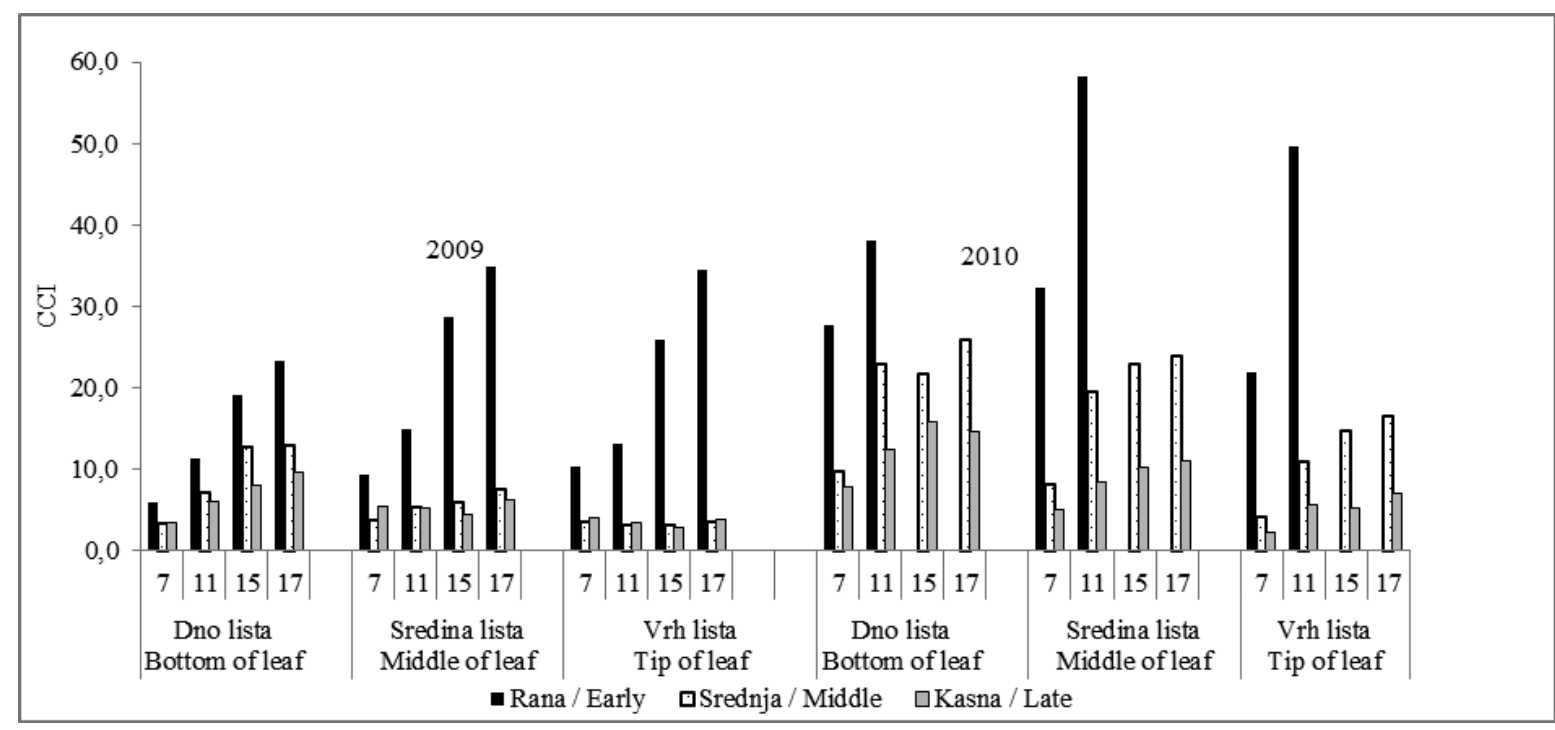

Slika. 1. Indeks sadržaja klorofila (CCI) u ranoj, srednjoj i kasnoj berbi na 7., 11., 15. i 17. listu izmjeren na dnu, sredini i vrhu listova u 2009. i 2010. U 2010. CCI za ranu berbu 15. i 17. list nisu analizirani

Figure. 1. Chlorophyll content index (CCI) in early, middle and late harvest at $7^{\text {th }}, 11^{\text {th }}, 15^{\text {th }}$ and $17^{\text {th }}$ leaf measured on bottom, middle and tip leaves in 2009 and 2010. In 2010, CCI for early harvest of $15^{\text {th }}$ and $17^{\text {th }}$ leaf was not analysed

U ovim istraživanjima je u obje godine generalno ustanovljen i trend povećanja jedinica indeksa sadržaja klorofila od nižih prema višim položajima na stabljici. Nadalje, kada su relativni sadržaji klorofila u 2009. bili izmjereni na sredini i na vrhu lista, razlike između srednje i kasne berbe bile su neznatne. Takvi rezultati vjerojatno su bili posljedica ograničene apsorpcije dušika zbog izuzetno male količine oborina tijekom vegetacije, što je rezultiralo prisilnom zriobom odnosno ranijom degradacijom klorofila na vrhu i u sredini listova. Iz takvoga zapažanja proizlazi da se relevantni podatci za procjenu zrelosti lista za berbu, u klimatski različitim godinama, postižu izmjerama indeksa sadržaja klorofila na dnu listova. Stoga se u daljnjim razmatranjima koriste podatci izmje- ra na dnu listova. Dosadašnja istraživanja upućuju na postojanje značajnoga odnosa između sadržaja klorofila $\mathrm{u}$ vrijeme berbe $\mathrm{s}$ kvantitativnim i kvalitativnim karakteristikama duhana (Walker, 1964.; Masclaux i sur., 2000.; Kowalczyk-Juśko i Kościk, 2002.; Kamarudin, 2003.; Liang i sur., 2008.; Gršić i Čavlek, 2010.).

Slika 2 pokazuje grafički prikaz i matematičke parametre odnosa između indeksa sadržaja klorofila u vrijeme berbe i prinosa, cijene, sadržaja nikotina i sadržaja reducirajućih šećera. Polinomni kvadratni matematički model je bolje pokazao odnos između indeksa sadržaja klorofila $\mathrm{i}$ istraživanih karakteristika nego linearni, posebice u 2009., pa su stoga prikazani 
samo rezultati te analize. Razvidna je slabija povezanost, iako značajna, u prvoj u usporedbi s drugom godinom istraživanja. Budući da su uzgojne mjere u obje godine bile jednake, neupitno je da je slabiji odnos između indeksa sadržaja klorofila i istraživanih karakteristika posljedica klimatskih uvjeta odnosno nedostatka i lošega rasporeda oborina tijekom vegetacije. S obzirom na utvrđeni utjecaj okolinskih čimbenika na odnos između indeksa sadržaja klorofila i istraživanih karakteristika, umjesto kritičnoga indeksa sadržaja klorofila prikladnije je koristiti se kritičnim rasponom indeksa sadržaja klorofila za procjenu zrelosti lista za berbu. $\mathrm{U}$ ovom istraživanju raspon indeksa sadržaja klorofila temeljio se na procjenama prikazanim u Slici 2. Cilj uzgoja duhana je postizanje optimalnih prinosa i cijene uz odgovarajuća kemijska svojstva, koja najbolje definiraju nikotin i reducirajući šećeri. Stoga su u pronalaženju optimalnoga raspona indeksa sadržaja klorofila u okviru kojega bi trebalo obaviti berbu listova duhana bili uključeni rezultati svih istraživanih karakteristika, a ne za svako svojstvo posebno. Rezultati ovoga istraživanja pokazali su da je optimalno vrijeme za berbu listova duhana bilo ono kada su se relativni sadržaji klorofila nalazili u rasponu od 11 do 15 jedinica. Gotovo identični rezultat za flue-cured duhan dobiven je ranije u sličnome istraživanju u istome uzgojnom području, ali s drugim faktorima i u drugačijim klimatskim uvjetima (Gršić i Čavlek, 2010.). Kamarudin (2003.) je pokazao da bi indeks sadržaja klorofila mogao biti pouzdan alat za procjenu zrelosti listova za berbu duhana tipa berlej.

Prije eventualne praktične uporabe rezultata ovih istraživanja trebalo bi proučiti i druge čimbenike koji nisu bili uključeni u ova istraživanja, primjerice sorte $s$ različitim obrascem dozrijevanja, $s$ navodnjavanjem ili bez njega, koji bi mogli utjecati na dozrijevanje listova $i$ posljedično na relativni sadržaj klorofila u vrijeme berbe.
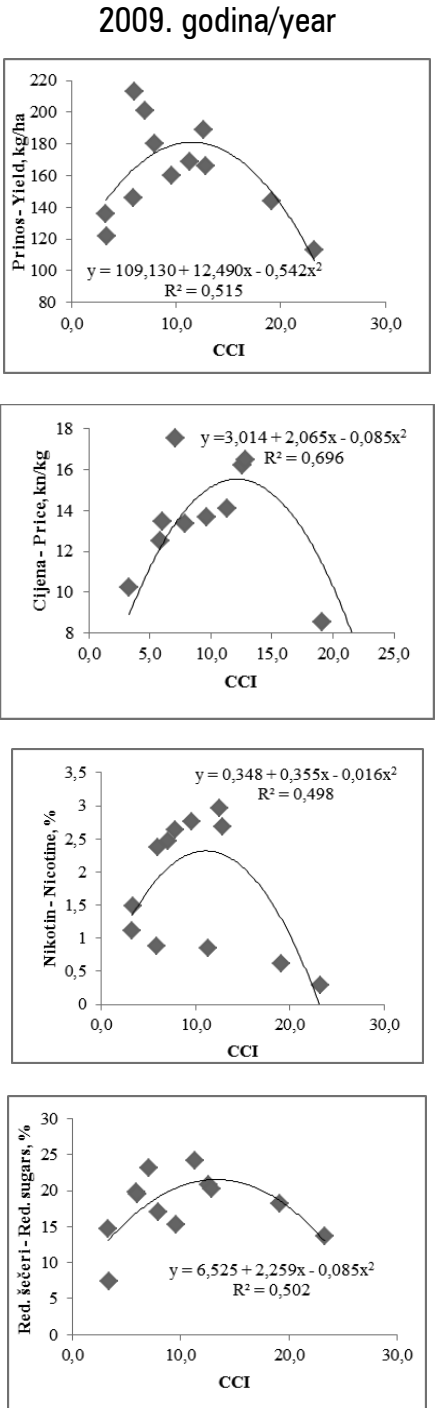

a)

2010. godina/year

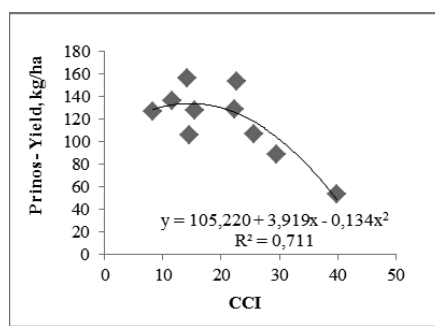

b)

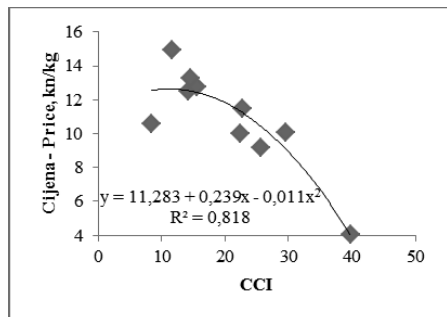

c)

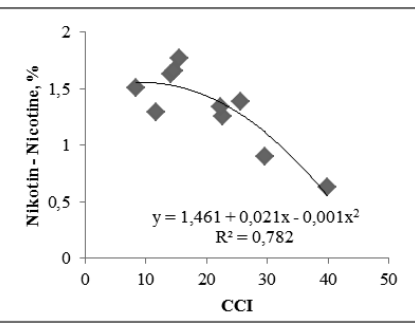

d)

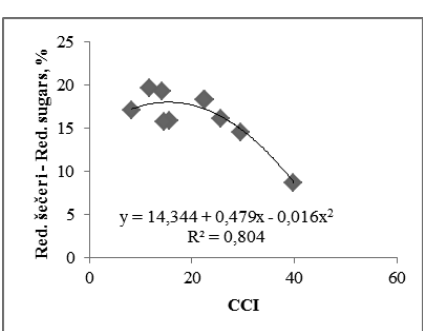

Slika 2. Odnosi između indeksa sadržaja klorofila (CCI) u vrijeme berbe i a) prinosa, b) cijene, c) sadržaja nikotina i d) sadržaja reducirajućih šećera u 2009. $(n=12)$ i 2010. $(n=10)$

Figure. 2. Relationships between chlorophyll content index (CCl) at harvest time and a) yield, b) price, c) nicotine content and d) reducing sugars content in $2009(n=12)$ and $2010(n=10)$ 


\section{ZAKLJUČAK}

Povećanje gnojidbe dušikom za $10 \mathrm{~kg} \mathrm{ha}^{-1}$ nije utjecalo na prosječan prinos, cijenu i sadržaj reducirajućih šećera, ali je u dva od osam mogućih slučajeva povećalo sadržaj nikotina.

Odlaganje berbe od rane do srednje ili/i kasne berbe, uz nekoliko iznimaka, rezultiralo je višim prinosom, cijenom, sadržajem nikotina i sadržajem reducirajućih šećera. Rezultati za agronomska i istraživana kemijska svojstva pokazali su da je optimalno vrijeme za berbu listova duhana bilo u rasponu indeksa sadržaja klorofila od 11 do 15.

\section{LITERATURA}

1. Çakir, R., \& Çebi, U. (2010). The effect of irrigation scheduling and water stress on the maturity and chemical composition of Virginia tobacco leaf. Field Crops Research, 119, (2-3), 269-276. https://dx.doi.org/10.1016/j.fcr.2010.07.017

2. Čavlek, M., \& Gršić, K. (2008). Effect of topping height, ripeness at harvest and cultivar on certain properties of leaves from the upper stalk position of flue-cured tobacco in Croatia. Cereal Research Communications, 36(3), Suppl. 5, 1664-1667.

3. Čavlek, M., Turšić, I., \& Berdin, M. (1988). Utjecaj primijenjene gnojidbe na neka svojstva virdžinijskih sorti duhana. I Agronomska svojstva. Tutun, 38(7-8), 223-232.

4. Drake, M. P., Vann, M. C., \& Fisher, L. R. (2015). Nitrogen application rate influence on yield, quality and chemical constituents of flue-cured tobacco, Part I: Application timing. Tobacco Science, 52, 11-17.

5. Gršić, K., \& Čavlek, M. (2010). Chlorophyll meter reading - a reliable tool for the estimation of tobacco leaf ripeness for harvesting. In CORESTA Congress, 12-16 September, Edinburgh, Scotland - UK (APPOST 10). Cooperation Centre for Scientific Research Relative to Tobacco (CORESTA)

6. Kamarudin, H. (2003). Maturity stages for stalk-cut burley tobacco and their relationships with leaf chlorophyll content. Journal of Tropical Agriculture and Food Science, 31(2), 157-163.

7. Kowalczyk-Juśko A., \& Kościk B. (2002). Possible use of the chlorophyll meter (SPAD-502) for evaluating nitrogen nutrition of the virginia tobacco. Electronic Journal of Polish Agricultural Universities, 5(1), 05.

8. Lyons D. J., Compton, B. L., \& Victor, P. (1996). A petiole sap nitrate test for management of nitrogen status and harvest initiation of flue-cured tobacco. Tobacco Science, 40, 130-136.

9. Liang, X. F., Wang, S. S., Shen, G. M., Wang. C. D., Chen, A. G., Liu, W. H., Chen, X. L., \& Dong, S. F., (2008). The prediction on maturity time of tobacco leaves based on the chlorophyll content and SPAD data. In CORESTA Congress, 2-7 November, Shanghai, China (APPOST 09). Cooperation Centre for Scientific Research Relative to Tobacco (CORESTA)

10. Masclaux, C., Valadier, M. H., Brugiere, N., MorotGaudry, J. F., \& Hirel, B. (2000). Characterization of the sink/source transition in tobacco (Nicotiana tabacum L) shoots to nitrogen management and leaf senescence. Planta, 211, 510-518. https://doi.org/10.1007/s004250000310

11. Steel, R. G. D., \& Torrie J. H. (1960). Principles and Procedures of Statistics. New York, Toronto, London. https://doi.org/10.1002/bimj.19620040313

12. Suggs, C.W. (1986). Effects of tobacco ripeness on yield, value, leaf chemistry and curing barn utilization potential. Tobacco Science, 30, 152-158.

13. Taylor, Z.G., Fisher, L.R., Smith, W.D., Edmisten, K.L. Wels, R., Jordan, D.L., \& Blankenship, S.M. (2011). The effects of 1-methylcyclopropene on ripening delay and holding ability in flue-cured tobacco. Tobacco Science, $48,15-19$ https://doi.org/10.3381/10-006.1

14. Walker, E. K. (1964). Some physical characteristics of cured leaves of flue-cured tobacco relative to chlorophyll content and color of green leaves. Tobacco Science, 8, 116-122.

15. Weybrew, J. A., Wan Ismail, W. A., \& Long, R. C. (1983). The cultural management of flue-cured tobacco quality. Tobacco Science, 27, 56-61.

16. Weybrew, J. A., Woltz; W. G., \& Monroe, R. J. (1984). Harvesting and curing of flue-cured tobacco. The effects of ripeness at harvest and duration of yellowing on yield, physical characteristics, chemical composition and smoker preference. NC Agricultural Technical Research Technical Bulletin, 275, 1-25. North Carolina State University, Raleigh, NC. 


\section{USE OF CHLOROPHYLL METER TO EVALUATE THE RIPENESS OF FLUE-CURED TOBACCO LEAVES FOR HARVESTING}

\section{SUMMARY}

In order to determine the possibility of using chlorophyll meter to estimate the optimal ripeness of flue-cured tobacco leaves for harvest, two-year field experiments were carried out. Treatments in the experiments were fertilization with nitrogen (25 and $35 \mathrm{~kg} \mathrm{ha}^{-1}$ ) and harvesting time (early, middle and late harvest). The relative chlorophyll content of leaves 7, 11, 15 and 17 was measured at harvest time. After harvesting and drying these leaves, yield and price, as well as the content of nicotine and reducing sugars, were analysed. There was no significant influence of nitrogen fertilization on average yield, price and reducing sugars content. However, two interactions fertilization $x$ harvesting time for yield were obtained. Higher nitrogen fertilization resulted in higher average nicotine content, but only in the $15^{\text {th }}$ and $17^{\text {th }}$ leaf in 2010. Given the time of harvest, the results of the research, with a few exceptions, showed that higher yields, prices, nicotine contents and reducing sugars contents were achieved in the middle and/or late harvest. To find the chlorophyll content index range within which the tobacco leaf harvests should be carried out, the mathematical parameters of the relationship between chlorophyll content index at harvest and investigated properties were used. In this study, the optimal time for tobacco leaf harvesting was in the chlorophyll content index range of 11 to $15 \mathrm{CCl}$.

Keywords: flue-cured tobacco, nitrogen fertilization, time of harvest, chlorophyll content index

(Primljeno 24. studenoga 2018.; prihvaćeno 10. listopada 2019. - Received on November 24, 2018; accepted on October 10, 2019) 